SODIUM: A FACTOR IN GROWTH OF BLUE-GREEN ALGAE

$$
\text { By }
$$

Amelia Kay Ward

\title{
A THESIS
}

Submitted to

Michigan State University

in partial fulfillment of the requirements

for the degree of

\section{MASTER OF SCIENCE}

Department of Botany and Plant Pathology 


\section{DISCLAIMER}

This report was prepared as an account of work sponsored by an agency of the United States Government. Neither the United States Government nor any agency Thereof, nor any of their employees, makes any warranty, express or implied, or assumes any legal liability or responsibility for the accuracy, completeness, or usefulness of any information, apparatus, product, or process disclosed, or represents that its use would not infringe privately owned rights. Reference herein to any specific commercial product, process, or service by trade name, trademark, manufacturer, or otherwise does not necessarily constitute or imply its endorsement, recommendation, or favoring by the United States Government or any agency thereof. The views and opinions of authors expressed herein do not necessarily state or reflect those of the United States Government or any agency thereof. 


\section{DISCLAIMER}

Portions of this document may be illegible in electronic image products. Images are produced from the best available original document. 


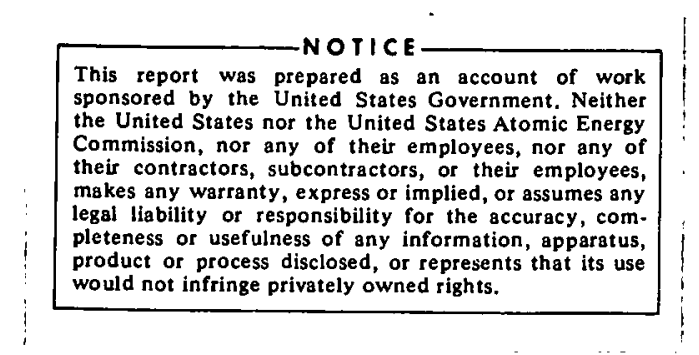

\section{ABSTRACT \\ SODIUM: A FACTOR IN GROWTH \\ OF BLUE-GREEN ALGAE}

\section{By}

Amelia Kay Ward

The response of heterocystous blue-green algae to varying concentrations of sodium was examined in axenic culture as well as in situ studies. Laboratory cultures of Anabaena cylindrica were treated with four concentrations of sodium and three concentrations of nitrate to determine the response in terms of rates of acetylene reduction, ${ }^{14} \mathrm{C}$ assimilation, excretion of organic carbon, concentration of chlorophyll a, particulate organic carbon, particulate organic nitrogen, and heterocyst and filament numbers. Natural populations of blue-green algae, predominantly Aphanizomenon sp., were used for sodium enrichment studies in which carbon-14 assimilation and acetylene reduction provided a measurement of comparative photosynthetic carbon fixation and elemental nitrogen fixation, respectively. Cultures of Anabaena cylindrica with no $\mathrm{Na}^{+}$added suffered from decreased rates of acetylene reduction;, ${ }^{14} \mathrm{C}$ assimilation, excretion of organic carbon as well as lower 
concentrations of chlorophyll a and particulate organic carbon compared to cultures supplied with 5, 10, and $50 \mathrm{mg}$ $\mathrm{Na}^{+}$liter ${ }^{-1}$. Sodium deficient cultures released a higher percentage of previously fixed carbon as organic carbon. No differences in any area measured were demonstrable among cultures grown with 5,10 , and $50 \mathrm{mg} \mathrm{Na}^{+}$liter ${ }^{-1}$. High nitrate concentrations ( $20 \mathrm{mg} \mathrm{NO}_{3}$ liter ${ }^{-1}$ ) resulted in decreased rates of acetylene reduction and heterocyst numbers in sodium sufficient and sodium deficient cultures; however, decreased particulate organic nitrogen content at high nitrate levels occurred only in sodium deficient cultures. Higher percentages of excreted organic carbon occurred with increasing nitrate concentrations in sodium deficient cultures. Sodium enrichment of natural phytoplankton populations indicated increased photosynthetic carbon fixation with small additions of sodium $\left(5 \mathrm{mg} \mathrm{Na}{ }^{+}\right.$ liter $\left.{ }^{-1}\right)$, whereas higher concentrations $(50,100$, and $200 \mathrm{mg} \mathrm{Na}^{+}$liter ${ }^{-1}$ ) elicited neither a stimulatory nor an inhibitory response. No increase in in situ acetylene reduction rates occurred with additions of sodium. 
SODIUM: A FACTOR IN GROWTH OF BLUE-GREEN ALGAE

By

Amelia Kay Ward

A THESIS

Submitted to Michigan State University

in partial fulfillment of the requirements for the degree of

MASTER OF SCIENCE

Department of Botany and Plant Pathology 


\section{ACKNOWLEDGMENTS}

I would like to express my sincere appreciation to Dr. Robert G. Wetzel for his continued guidance and support throughout the investigatory aspects of this study as well as in the preparation of the manuscript. Appreciation is also extended to Drs. Wetzel, Michael J. Klug, and Peter G. Murphy for their critical evaluation of the manuscript. The use of gas chromatographic equipment, generously made available by Dr. Klug, is gratefully acknowledged. Invaluable discussions with Gordon L. Godshalk, Donna K. King, Kelton R. McKinley, and Grover M. Ward as well as the technical expertise of Jayashree Sonnad aided immensely in the completion of this project.

This research was supported financially by AEC Grant AT-(11-1)-1599, COO-1599-84 . 
TABLE OF CONTENTS

Page

LIST OF TABLES • • • • • • • • • • • • • • • • • •

LIST OF FIGURES.

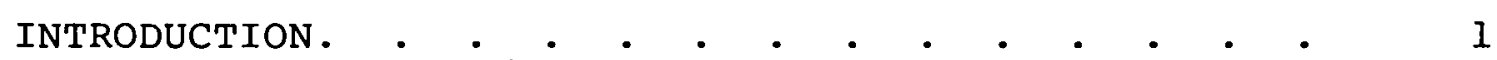

MATERIALS AND METHODS. • • • . . . . . . . . 5

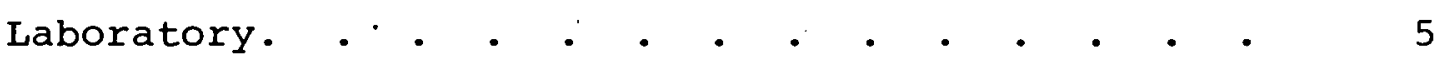

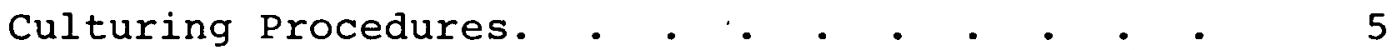

Acetylene Reduction . . . . . . . . . . 47

Chlorophyll a. . . . . . . . . . . . . 8

Carbon Assimilation and Excreted organic

Carbon.

Particulate Organic Carbon. . . . . . . . . 9

Particulate Organic Nitrogen . . . . . . . . 99

Filament and Heterocyst Enumeration. . . . . 10

Sodium Analysis . . . . . . . . . . . . 10

Field Procedures. • • • • • . . . . . . . 10

Carbon-14 Sodium Enrichment Bioassays . . . . 10

Acetylene Reduction Enrichment Bioassays . . . 11

Enumeration of Algal Cells and Heterocysts . . 12

RESULTS AND DISCUSSION

Response of Anabaena cylindrica to Sodium . . . . 13

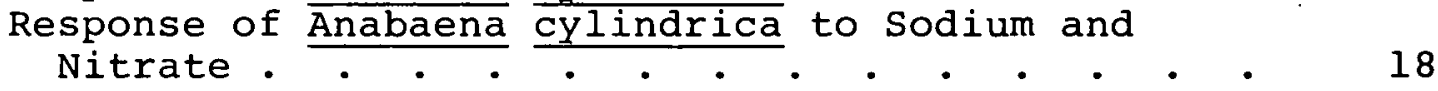

Response of Natural Populations of Blue-green
Algae to Sodium Enrichment. . . . . . . . . $\quad 28$

SUMMARY AND CONCLUSIONS • • • • • • • • • • • • • $\quad 35$

BIBLIOGRAPHY • • • • • • • • • • • • • • • 


\section{LIST OF TABLES}

Table

1. Results of two-way analysis of variance

on data from axenic cultures of Anabaena

cylindrica in response to sodium and

nitrate, including levels of signifi-

cance: $\star \star, P<0.01 ; *, \mathrm{P}<0.05 ; \mathrm{n} . \mathrm{s}$.,

not significānt

2. Major groups of algae present on 11 July 74 at 0.5 meters in Wintergreen Lake.. . . 


\section{LIST OF FIGURES}

\section{Figure}

1. Concentration of chlorophyll a and rates of acetylene reduction of axenic Anabaena cylindrica over time at four concentrations of sodium and three concentrations of nitrate. Standard deviations are given for acetylene reduction unless one standard deviation is less than the diameter of the point. Sodium concentrations (mg Iiter ${ }^{-1}$ ): 0 - --・; 5 - ; $10 \cdot-\cdot \cdot 50 \cdots \cdots \cdot$. . . . . . • .

2. Rates of ${ }^{14} \mathrm{C}$ assimilation and excretion of organic carbon $(t S . D$.$) of axenic$ Anabaena cylindrica . . . . . . .

3. Excreted organic carbon as percentage carbon assimilated ( $($ S.D.) of axenic Anabaena cylindrica on day 14 . . . .

4. Concentration of particulate organic carbon (t S.D.) of axenic Anabaena

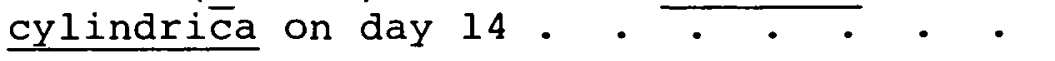

5. Concentration of chlorophyll a and rates of acetylene reduction of Anabaena cylindrica over time at two concentrations of sodium and three concentrations of nitrate. Standard deviations are included unless one standard deviation was less than the diameter of the point.

6. Density of filaments and heterocysts $\left(\mathrm{ml}^{-1}\right)$ on day 14 of axenic Anabaena cylindrica in response to variations in sodium and nitrate. Standard deviations are. included unless one standard deviation was less than the width of the line. . . 
7. Concentrations ( \pm S.D.) of particulate organic carbon and particulate organic nitrogen on day 14 of Anabaena cylindrica in response to variations in

8. Rates of ${ }^{14} \mathrm{C}$ assimilation and excretion of organic carbon $( \pm$ S.D.) on day 14 of Anabaena cylindrica in response to varying sodium and nitrate . . . .

9. Excreted organic carbon as percentage carbon assimilated ( + S.D.) on day 14 of Anabaena cylindrica in response to varying sodium and nitrate . . . .

10. Photosynthetic carbon fixation and excreted organic carbon of phytoplankton populations in response to sodium enrichment, 16 July 73, in Wintergreen Lake over a 12-hour incubation period. Lakewater control - $; 50 \mathrm{mg} \mathrm{Na}^{+}$ liter ${ }^{-1} \cdot{ }^{-} ;$; $100 \mathrm{mg} \mathrm{Na}{ }^{+}$liter ${ }^{-1} \ldots$. ; $200 \mathrm{mg} \mathrm{Na}{ }^{\mp}$ liter ${ }^{-1} \cdot . \cdot-\cdot$

11. (a) Photosynthetic carbon fixation, (b) rates of excretion of organic carbon, and (c) acetylene reduction of phytoplankton populations in response to sodium enrichment, $11 \mathrm{July} 74$, in Wintergreen Lake at 0.5 meters. $0=$ lakewater control (t S.D.) 
INTRODUCTION

Several investigators have reported positive growth responses in blue-green algal cultures to the presence of relatively high concentrations of sodium (Allen, 1952; Batterton \& Van Baalan, 1971; Benecke, 1898; Emerson \& Lewis, 1942; Gerloff, et al., 1952; and Kratz \& Myers, 1955). Maximum growth was obtained at various levels ranging from one $\mathrm{mg} \mathrm{Na}^{+}$liter ${ }^{-1}$ and higher for Anacystis $\underline{\text { nidulans (Batterton \& Van Baalan, 1971), } 5 \mathrm{mg} \mathrm{Na}^{+} \text {liter }}{ }^{-1}$ and higher for Anabaena cylindrica (Allen \& Arnon, 1955) to $40 \mathrm{mg} \mathrm{Na}{ }^{+}$liter $^{-1}$ for Anabaena variabilis and Anacystis nidulans (Kratz \& Myers, 1955). Blue-green algae are among the few plants which have an absolute sodium requirement (Allen \& Arnon, 1955). In studies with Anabaena cylindrica the criteria for an essential nutrient were defined as follows: (1) normal plant growth is absent without the element; (2) the deficiency symptoms caused by the absence of the element are removed on its addition to the medium; (3) the requirement is specific (the substitution of another nutrient for the element cannot be made); and 
(4) the function of the element or its direct effect on the metabolism of the plant is identified.

The physiological function of sodium in blue-green algae has never been elucidated completely. Sodium has been shown to inhibit nitrate reductase activity in cultures of Anabaena cylindrica grown with nitrate (Brownell \& Nicholas, 1967). Sodium deficient cultures resulted in enhanced nitrate reductase activity and accumulation of toxic levels of nitrate. Higher levels of sodium were required to avoid deficiency symptoms in cultures grown with nitrate $(0.4 \mathrm{meq} / \mathrm{l} \mathrm{NaCl})$ as compared with cultures grown without nitrate $(0.004 \mathrm{meq} / 1 \mathrm{NaCl})$.

The paucity of information regarding the physiological function of sodium is matched by the lack of information on the possible ecological effects of sodium on natural populations of blue-green algae. Provasoli (1969) conjectured that increases in salinity in. Lake Washington could have been a contributory factor to the ensuing blue-green algal bloom (Edmondson, et al., 1956). The presence of both high levels of sodium $\left(50 \mathrm{mg} \mathrm{Na}^{+}\right.$ liter ${ }^{-1}$, and dense populations of blue-green algae have been noted in hypereutrophic Sylvan Lake in contrast to low levels of sodium ( $3 \mathrm{mg}$ liter ${ }^{-1}$ ) and a lack of blue-green dominant populations in Goose Lake and hard-water lakes in general (Wetzel, 1966). The occurrence of the two phenomena may be unrelated, but the possibility of sodium contributing 
as one of several interrelated causal factors appears worthy of further investigation.

Ecologically, nitrogen-fixing blue-green algae are of particular interest because of their potential to contribute simultaneously to the carbon and nitrogen input of certain water strata. Large populations of heterocystous blue-green algae and maximum nitrogen-fixing rates are generally associated, spatially and temporally, with minimal concentrations of combined inorganic nitrogen forms (Goering \& Neess, 1964; Stewart, et al., 1970; Duong, 1972; Horne \& Goldman, 1972; Horne, et al., 1972). However, the presence of inorganic forms does not necessarily preclude elemental nitrogen fixation (Dugdale \& Dugdale, 1965; Goering \& Dugdale, 1966; Horne \& Fogg, 1970). The understanding of the effects of any factor which has the potential to influence directly the nitrogen metabolism of heterocystous blue-green álgae would seem of major importance in further clarifying the many complex interactions which result in the presence of natural populations of heterocystous blue-green algae. Sodium has been implicated as such a factor.

The primary objective of the following study was to investigate the response of blue-green algae to various levels of sodium concentration. It was restricted to nitrogen-fixing members of the Cyanophyta with major emphasis on facets of carbon and nitrogen metabolism. The research followed two directions: 
1. Assays of the response of Anabaena cylindrica in axenic culture to varying concentrations of sodium and nitrate.

2. In situ studies designed to describe the response of natural populations of heterocystous bluegreen algae to sodium enrichment by means of carbon-14 radioassay as well as acetylene reduction techniques. 


\section{MATERIALS AND METHODS}

\section{Laboratory}

\section{Culturing Procedures}

A culture of Anabaena cylindrica, generously supplied by Professor Akihiko Hattori, University of Tokyo, Tokyo, Japan, was maintained in axenic culture for laboratory experiments. The medium used for experimental purposes, G4 (a modification of Gorham's medium), was of the following composition (mg liter $\left.{ }^{-1}\right): \mathrm{K}_{2} \mathrm{CO}_{3}, 26$; $\mathrm{K}_{3} \mathrm{C}_{6} \mathrm{H}_{5} \mathrm{O}_{7} \cdot \mathrm{H}_{2} \mathrm{O}, 235 ; \mathrm{K}_{2} \mathrm{HPO}_{4}, 39 ; \mathrm{MgSO}_{4} \cdot 7 \mathrm{H}_{2} \mathrm{O}, 75 ; \mathrm{CaCl}_{2}, 27$; ferric citrate, 6; nitrilotriacetic acid, 40. Potassium nitrate was used in medium containing nitrate. Sodium was variable and added as $\mathrm{NaCl}$. Micronutrients were supplied as follows (mg liter ${ }^{-1}$ ): $\mathrm{ZnSO}_{4} \cdot \mathrm{7H}_{2} \mathrm{O}, 1 ; \mathrm{MnSO}_{4} \cdot \mathrm{H}_{2} \mathrm{O}, 1$; LiCl，0.5; $\operatorname{CoCl}_{2} \cdot 6 \mathrm{H}_{2} \mathrm{O}, 0.5 ;\left(\mathrm{NH}_{4}\right)_{6} \mathrm{MO}_{7} \mathrm{O}_{24} \cdot 4 \mathrm{H}_{2} \mathrm{O}, 0.1$. The $\mathrm{pH}$ was adjusted to 7.0 with $0.5 \mathrm{~N} \mathrm{KOH}$ before autoclaving; final $\mathrm{pH}$ after autoclaving was 7.9. The medium was dispensed in $300 \mathrm{ml}$ aliquots to $500 \mathrm{ml}$ polycarbonate flasks. Polycarbonate was used to prevent $\mathrm{Na}^{+}$contamination from glass flasks. G4 medium with no NaCl added, autoclaved once in a polycarbonate flask and stored for 26 days was 
found to have an absolute $\mathrm{Na}^{+}$concentration of $0.236 \mathrm{mg}$ $\mathrm{Na}^{+}$liter ${ }^{-1}$ compared with $0.661 \mathrm{mg} \mathrm{Na}^{+}$liter $^{-1}$ in medium autoclaved once in a glass flask and stored for the same period of time. Repeated autoclaving also increased the sodium concentration of the medium in a glass flask, whereas no increase in sodium concentration was observed in medium repeatedly autoclaved in a polycarbonate flask. Sodium concentrations in the text and figures refer to sodium added as $\mathrm{NaCl}$, not the absolute sodium concentration of the medium.

An aliquot from a fresh stock culture was used as an inoculum for experimental flasks. Twenty ml of stock culture were transferred aseptically to $100 \mathrm{ml}$ G4 medium without sodium in a glass flask; twenty ml from this flask were then transferred to $100 \mathrm{ml}$ G4 medium without sodium in a polycarbonate flask. A two $\mathrm{ml}$ aliquot from the polycarbonate flask was used as an inoculum for each experimental flask, thus, sufficiently diluting the sodium from the stock culture. Duplicate flasks of all treatments were prepared in each experiment. Experimental cultures were maintained in a sherer growth chamber on a rotating platform at $23^{\circ} \mathrm{C}$ and at a light intensity of 1936 lux (Weston Illumination Meter, Model 756) supplied from fluorescent and incandescent light sources on a light regime of 16 hours light and 8 hours dark. 


\section{Acetylene Reduction}

The acetylene reduction technique for determination of elemental nitrogen fixation was first developed (Dilworth, 1966; Schöllhorn \& Burris, 1966) and applied to blue-green algae in the mid-1960s (Stewart, et al., 1967, 1968). Since then it has been used extensively in both laboratory and in situ studies. However, it is an indirect technique and not without problems (see discussion in Fogg, et al., 1973, and Stewart, 1973). In this study it was used as a reasonable estimate of the comparative $\mathrm{N}_{2}$-fixing ability of heterocystous blue-green algae. Aliquots $(5 \mathrm{ml})$ from each culture flask were transferred aseptically to a $15 \mathrm{ml}$ serum vial and sealed with serum bottle caps. Vials were flushed for two minutes with a nitrogen-free gas: $\mathrm{CO}_{2}, 0.0395 \% ; \mathrm{O}_{2}, 23.608$, argon balance (Matheson Gas Products, Joliet, Illinois), injected with $1.0 \mathrm{ml}$ purified acetylene (Matheson Gas Products), and incubated two hours under the same conditions as the culture flasks. The algae were killed with $0.2 \mathrm{ml} 28 \mathrm{HgCl}_{2}$. Control vials were injected with $\mathrm{HgCl}_{2}$ immediately after injection of acetylene and allowed to incubate under the same conditions as the experimental vials. Samples $(1.0 \mathrm{ml})$ from the headspace were injected into a Packard 409 gas chromatograph equipped with a $\mathrm{H}_{2}$-flame ionization detector. A stainless steel column ( $3 \mathrm{~mm}$ X 2 meters) packed with Porapak-N (80-100 Mesh) was used for all analyses. Oven temperature was $65^{\circ} \mathrm{C}$. Flow rates of gases 
were as follows: He, $11 \mathrm{ml}$ minute ${ }^{-1} ; \mathrm{H}_{2}, 18 \mathrm{ml}$ minute $^{-1}$; air, $240 \mathrm{ml}$ minute ${ }^{-1}$. Areas of ethylene peaks (height of peak $\mathrm{X}$ width at $1 / 2$ peak height) were quantified by relating the areas of the peaks to a known series of standards of purified ethylene (Matheson Gas Products).

Chlorophyll a

Aliquots ( 5 or $10 \mathrm{ml}$ ) were withdrawn aseptically from each culture flask and filtered onto a Millipore AA filter. Filters were homogenized (Teflon homogenizer) in $90 \%$ basic aqueous acetone, centrifuged, and the absorption of the supernatant measured by a Hitachi-Perkin Elmer spectrophotometer (Model UV-VIS 139). Calculations were those from Parsons and Strickland (1963) modified by Westlake (1969). Corrected chlorophyll a and pheopigments were also measured using the equations of Parsons and Strickland (1963) modified by Wetzel and Westlake (1969).

Carbon Assimilation and Excreted Organic Carbon

The day an experiment was terminated, a $35 \mathrm{ml}$ aliquot was withdrawn from each experimental flask and placed in a sterile $100 \mathrm{ml}$ erlenmeyer flask. Either $400 \mathrm{\mu l}$ or $100 \mathrm{\mu l}$ of $\mathrm{KH}^{14} \mathrm{CO}_{3}\left(4.96 \mu \mathrm{Ci} \mathrm{mi}{ }^{-1}\right)$ were injected into each flask. After a two hour incubation period under the same conditions as the experimental flasks, duplicate $5.0 \mathrm{ml}$ aliquots were filtered onto Millipore HA filters for Geiger-Müller radioassay (Nuclear-Chicago D-47 of known 
counting efficiency). Excreted organic carbon was measured from the same flasks. Ten $m l$ of culture sample were filtered onto a Millipore HA filter; the filtrate was acidified with $3 \% \mathrm{H}_{3} \mathrm{PO}_{4}$, purged with $\mathrm{N}_{2}$ for two minutes, and two $\mathrm{ml}$ pipetted onto planchets for radioassay as above.

\section{Particulate Organic Carbon.}

The day an experiment was terminated, duplicate $25 \mathrm{ml}$ samples from each experimental flask were filtered onto pre-combusted (45 minutes, $525^{\circ} \mathrm{C}$ ) glass fiber filters (Reeve Angel, 984H). Filters were analyzed for carbon by the procedures of Strickland and Parsons (1968) in which wet oxidation by acid dichromate is used with dextrose (D-glucose) as a standard.

\section{Particulate Organic Nitrogen}

Samples to be analyzed for particulate organic nitrogen were filtered by the same procedure as those for particulate organic carbon. Filters were subjected to a modification of the Kjeldahl determination described by McKenzie and Wallace (1954). Filters were predigested overnight in four $\mathrm{ml}$ of concentrated $\mathrm{H}_{2} \mathrm{SO}_{4}$ with $150 \mathrm{mg}$ salicylic acid. After the addition of $300 \mathrm{mg} \mathrm{Na} \mathrm{S}_{2} \mathrm{O}_{3} \cdot 5 \mathrm{H}_{2} \mathrm{O}$, $3 \mathrm{~g} \mathrm{~K} \mathrm{SO}_{4}$, and $150 \mathrm{mg} \mathrm{HgO}$, samples were digested over heat until clear and then refluxed for 45 minutes. Samples were steam distilled, using methyl red in dilute boric acid as an indicator, and titrated against $0.005 \mathrm{~N} \mathrm{HCl}$. An indicator blank was used for the determination of the endpoint. 
Filament and Heterocyst

Enumeration

Samples from each culture flask were preserved with Lugol's solution. One $\mathrm{ml}$ was transferred to a SedgewickRafter chamber for counting at $150 \mathrm{x}$.

\section{Sodium Analysis}

Sodium concentrations of culture media and filtered lakewater samples were measured with a Jarrell Ash atomic absorption spectrophotometer (Model 82-700).

\section{Field Procedures}

Carbon-14 Sodium Enrichment Bioassays

Water samples were collected with a Van Dorn water sampler and distributed to $500 \mathrm{ml}$ erlenmeyer flasks (summer, 1973) or $125 \mathrm{ml}$ bottles (summer, 1974). Samples were injected with $\mathrm{NaCl}$ from autoclaved stock solutions to yield a final known $\mathrm{Na}^{+}$concentration. Three replicate light bottles and one dark bottle were used for each concentration as well as for untreated lakewater controls. Bottles were injected with $1.0 \mathrm{ml} \mathrm{KH}^{14} \mathrm{CO}_{3}\left(4.96 \mu \mathrm{Ci} \mathrm{ml}{ }^{-1}\right)$, suspended at the depth from which the water was collected and allowed to incubate. After incubation, $25 \mathrm{ml}$ aliquots were filtered onto Millipore HA filters, fumed with HCl (Wetzel, 1965a) and analyzed by radioassay as described in Laboratory Procedures. 
Acetylene Reduction Enrichment

Bioassays

Methods of in situ acetylene reduction followed closely those described by Duong (1972). Water samples were collected and the algae concentrated by gently filtering one liter of lakewater through $30 \mu \mathrm{m}$ Nitex netting; algae were kept suspended in a small amount of filtrate during filtration to prevent disruption of cells and then rinsed from the netting into a beaker and resuspended in $100 \mathrm{ml}$ of lakewater filtrate. Aliquots $(7 \mathrm{ml})$ from this sample were distributed to $15 \mathrm{ml}$ serum vials, injected with $0.5 \mathrm{ml}$ of an appropriate $\mathrm{NaCl}$ solution, stoppered, flushed for two minutes with nitrogen-free gas (see Laboratory Procedures), injected with $1.0 \mathrm{ml}$ acetylene, resuspended at the depth from which the water was collected, and incubated for two hours. Three replicate vials were used for each sodium concentration as well as for untreated lakewater samples. The algae were killed with $0.2 \mathrm{ml} 2 \%$ $\mathrm{HgCl}_{2}$. Controls were injected with $\mathrm{HgCl}_{2}$ immediately after injection with acetylene and incubated with experimental vials. Vials were brought to the laboratory and $1.0 \mathrm{ml}$ of headspace gas injected into a Varian Aerograph gas chromatograph (Model 500-D) with a flame ionization detector. A stainless steel column ( $3 \mathrm{~mm}$ x 2 meters) packed with Porapak-N (80-100 mesh) was used for all analyses. Flow rates of the gases were as follows: He, $18 \mathrm{mi}$ minute ${ }^{-1} ; \mathrm{H}_{2}, 25 \mathrm{ml}$ minute ${ }^{-1} ;$ and air, $18 \mathrm{ml}$ minute ${ }^{-1}$. 
Column temperature was $50^{\circ} \mathrm{C}$. Ethylene was quantified as described in Laboratory Procedures.

Enumeration of Algal Cells

and Heterocysts

Phytoplankton samples were preserved with Lugol's

solution, $5 \mathrm{ml}$ placed in a settling chamber and counted at $200 \mathrm{x}$ using a wild inverted microscope. 


\section{RESULTS AND DISCUSSION}

$\frac{\text { Response of Anabaena }}{\text { cylindrica to Sodium }}$

The first three experiments were designed to determine if varying levels of sodium elicit different responses from the laboratory culture of Anabaena cylindrica. Four concentrations of sodium at one concentration of nitrate were used in each experiment, the nitrate level varying in each experiment. However, the exact values obtained in one experiment cannot be compared directly with values in other experiments because of variations in initial inoculum cell density. Therefore, only the responses to four concentrations of sodium at a given level of nitrate were compared.

The greatest difference in rates of acetylene reduction at each concentration of nitrate occurred between the levels of 0 and $5 \mathrm{mg} \mathrm{Na}^{+}$liter $^{-1}$ (Figure 1). Nested one-way analyses of variance revealed a significant difference in the acetylene reduction rates on day 14 among sodium treatments at the $1 \%$ level $(P \leq 0.01)$. Little difference resulted from concentrations of sodium at 5,10 , and $50 \mathrm{mg} \mathrm{Na}^{+}$liter ${ }^{-1}$. Increases in concentrations of 


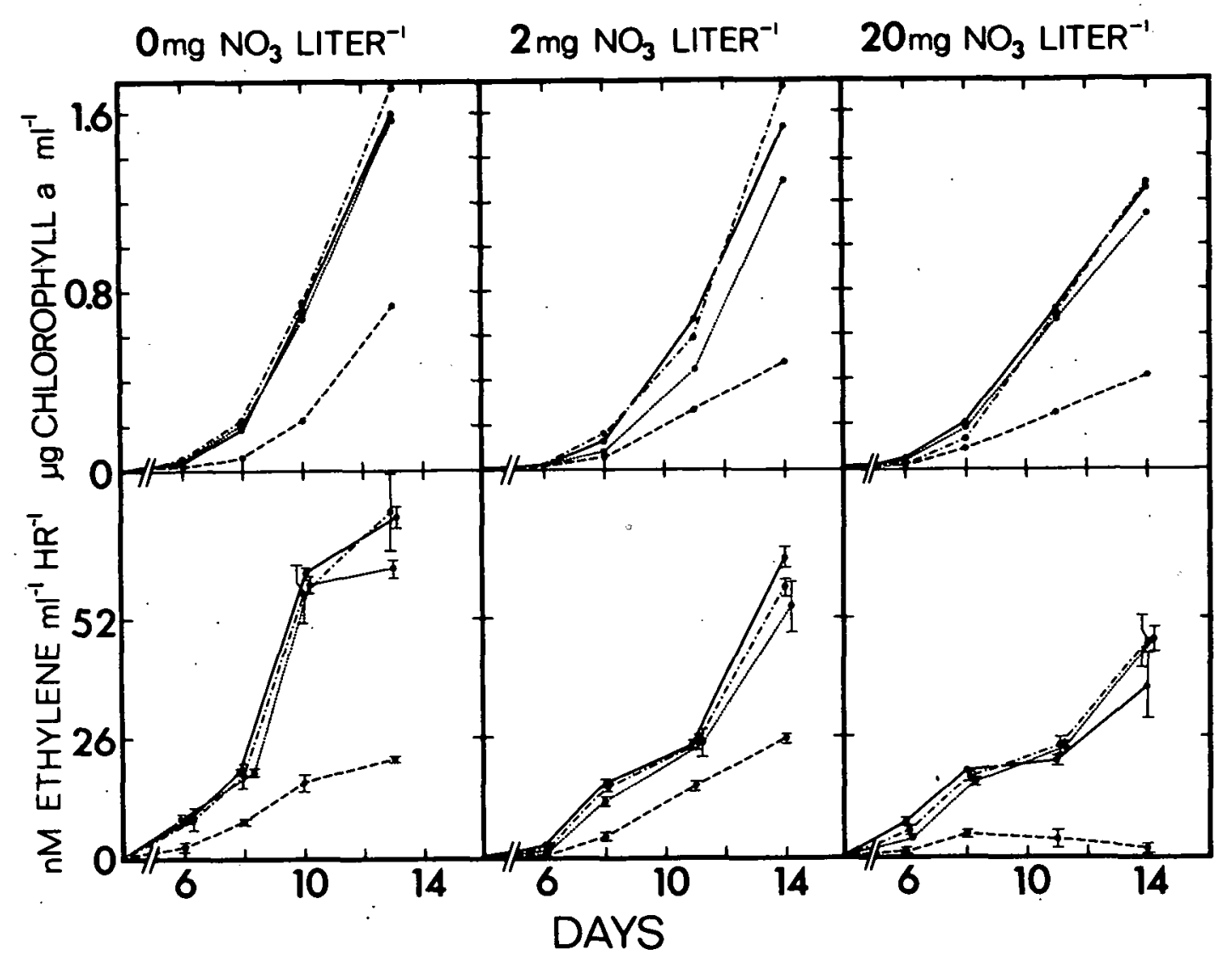

Figure 1. Concentration of chlorophyll a and rates of acetylene reduction of axenic Anabaena cylindrica over time at four concentrations of sodium and three concentrations of nitrate. Standard deviations are given for acetylene reduction unless one standard deviation is les than the diameter of the point. Sodium concentrations (mg liter ${ }^{-1}$ ): $0 \cdots \ldots ; 5 \cdot \ldots$; $; 10 \cdot \ldots \cdot \cdot 50 \cdots$; 50. 
chlorophyll a, used as an estimate of increasing biomass, closely resembled increases in rates of acetylene reduction (Figure 1). The only exception to this was the treatment in which cultures grown with $0 \mathrm{mg} \mathrm{Na}^{+} 1$ liter $^{-1}$ and an initial concentration of $20 \mathrm{mg} \mathrm{NO}_{3} 1$ iter $^{-1}$ reached a maximum acetylene reduction rate on day 8 and decreased steadily to an almost negligible rate on day 14 . However, concentrations of chlorophyll a in the same treatment continued to increase over the same period of time. This was the only treatment in which the acetylene reduction rate decreased with time.

$$
\text { Rates of }{ }^{14} \mathrm{C} \text { assimilation reflected a pattern }
$$

similar to that of acetylene reduction; that is, carbon uptake in cultures without sodium was consistently onethird that of cultures grown at the three other concentrations of sodium (Figure 2). No marked differences were found among the higher sodium concentrations. In contrast to rates of ${ }^{14} \mathrm{C}$ assimilation, rates of excretion of organic carbon in cultures with no added sodium were approximately one-half those of cultures with added sodium (Figure 2). The relationship between rates of excreted organic carbon and rates of ${ }^{14} \mathrm{C}$ assimilated can be seen more clearly when excreted organic carbon is expressed as per cent carbon assimilated (Figure 3 ). In all experiments a greater percentage of carbon assimilated (as inorganic ${ }^{14} \mathrm{C}$ ) was excreted as organic carbon in cultures with no added sodium. Although the actual percentages were small, this is a 


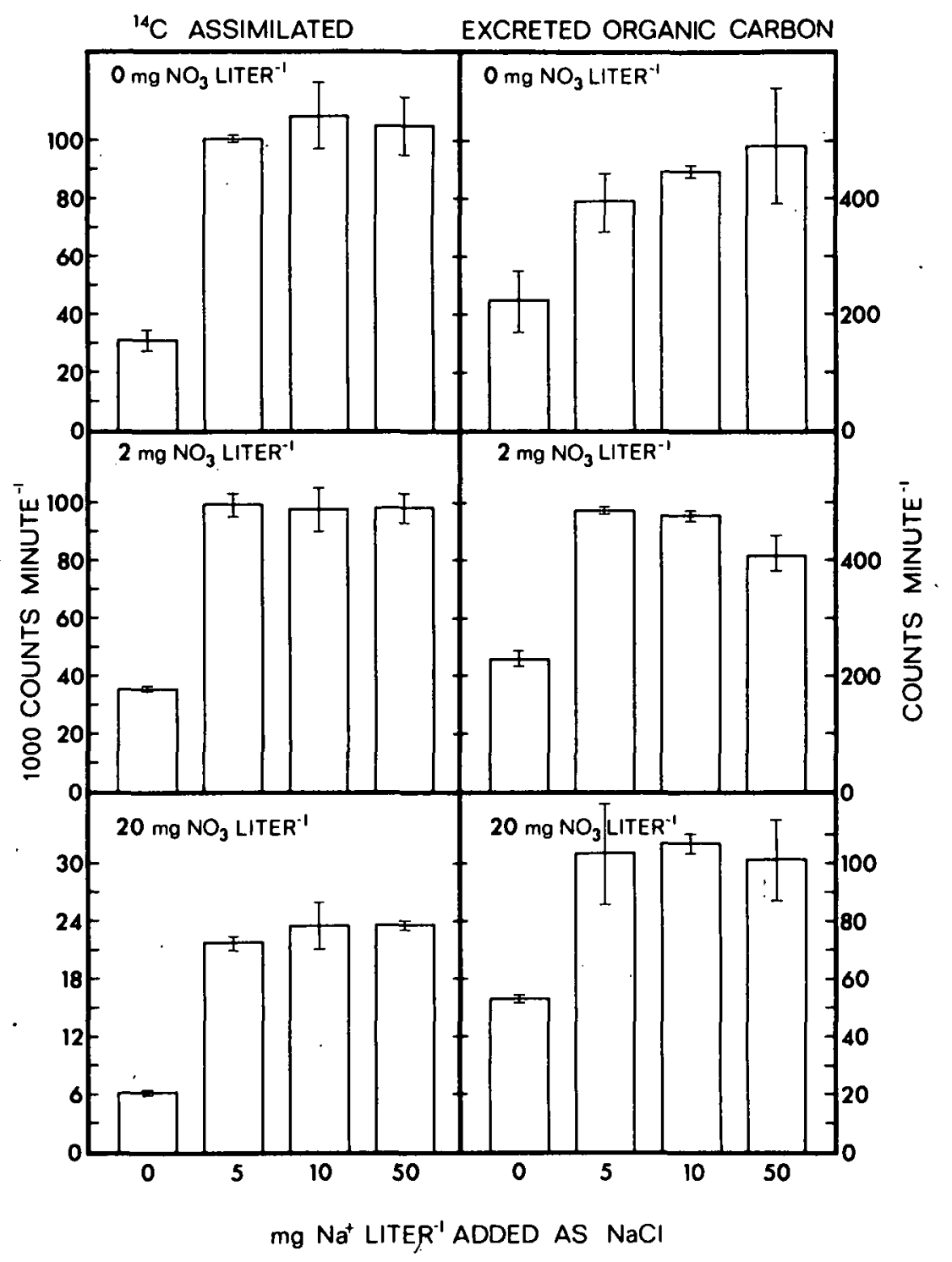

Figure 2. Rates of ${ }^{14} \mathrm{C}$ assimilation and excretion of organic carbon ( $t$ S.D.) of axenic Anabaena cylindrica. 


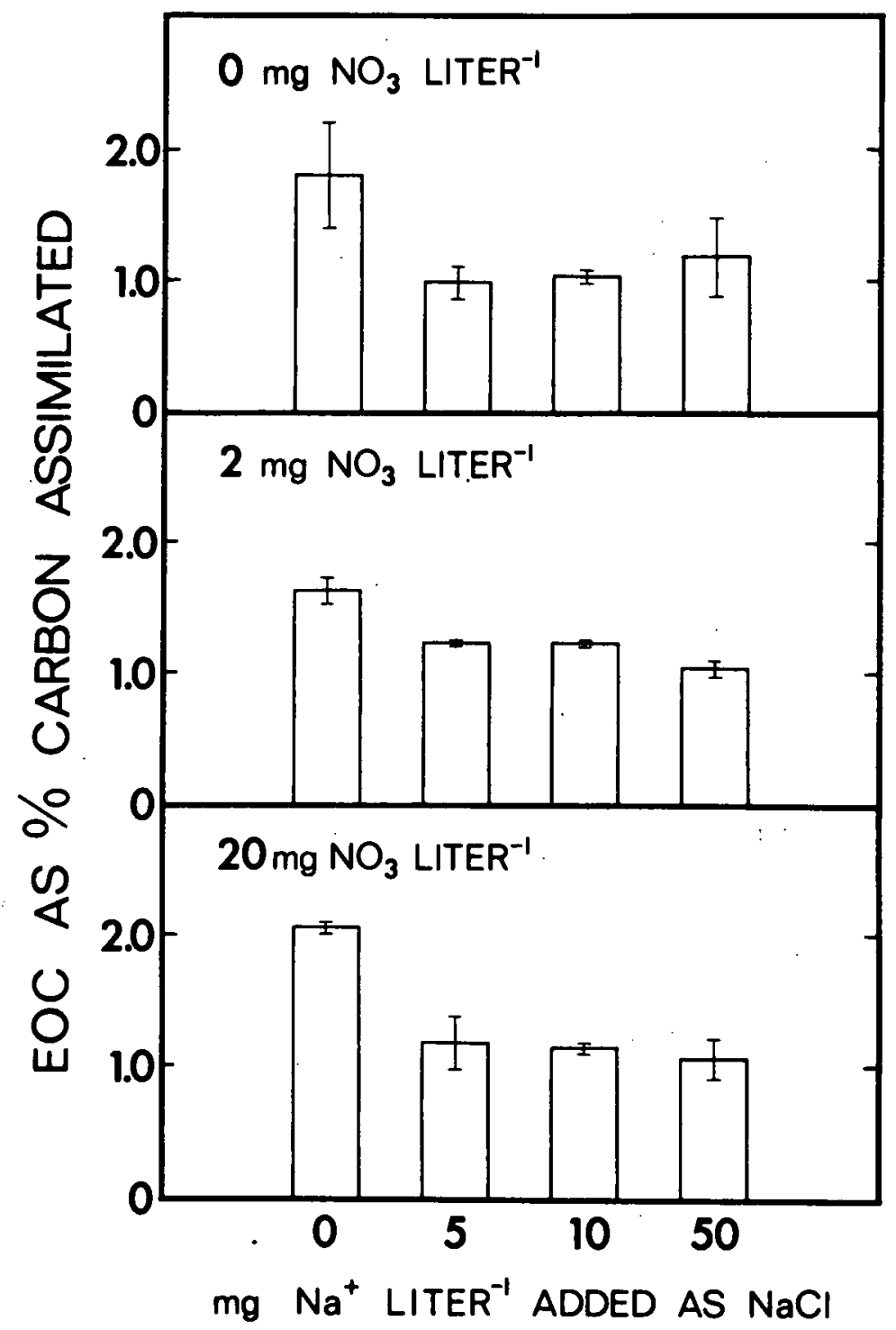

Figure 3. Excreted organic carbon as percentage carbon assimilated (t S.D.) of axenic Anabaena cylindrica on day 14 . 
probable indication of a less efficient system in terms of carbon utilization in the sodium deficient cultures.

The quantity of particulate organic carbon present in cultures with added sodium was consistently twice that present in cultures without sodium (Figure 4). Since rates of carbon assimilation in cultures with added sodium were at least three times that of sodium deficient cultures, there appears to be a loss of carbon after assimilation in cultures with added sodium not entirely explicable in terms of excreted organic carbon. Possible explanations include: (1) Higher rates of $\mathrm{CO}_{2}$ evolution occurred in sodium sufficient cultures. (2) Rates of ${ }^{14} \mathrm{C}$ assimilation in sodium sufficient cultures were less than three times that of sodium deficient cultures prior to day 14. Rates of ${ }^{14} \mathrm{C}$ assimilation were measured only on the last day of the experiment; the particulate organic carbon represented an accumulation over a 14-day period. Both explanations are entirely speculative since no data are available on $\mathrm{CO}_{2}$ evolution or rates of ${ }^{14} \mathrm{C}$ assimilation prior to the 14 th day of the experiments.

\section{Response of Anabaena cylindrica to Sodium and Nitrate}

In order to investigate responses to nitrate and sodium, experiments were designed to compare two concentrations of sodium ( 0 and $5 \mathrm{mg} \mathrm{Na}^{+}$liter $\left.{ }^{-1}\right)$ at three concentrations of nitrate $\left(0,2\right.$, and $20 \mathrm{mg} \mathrm{NO}_{3}$ liter $\left.{ }^{-1}\right)$. The two concentrations of sodium were found to produce 


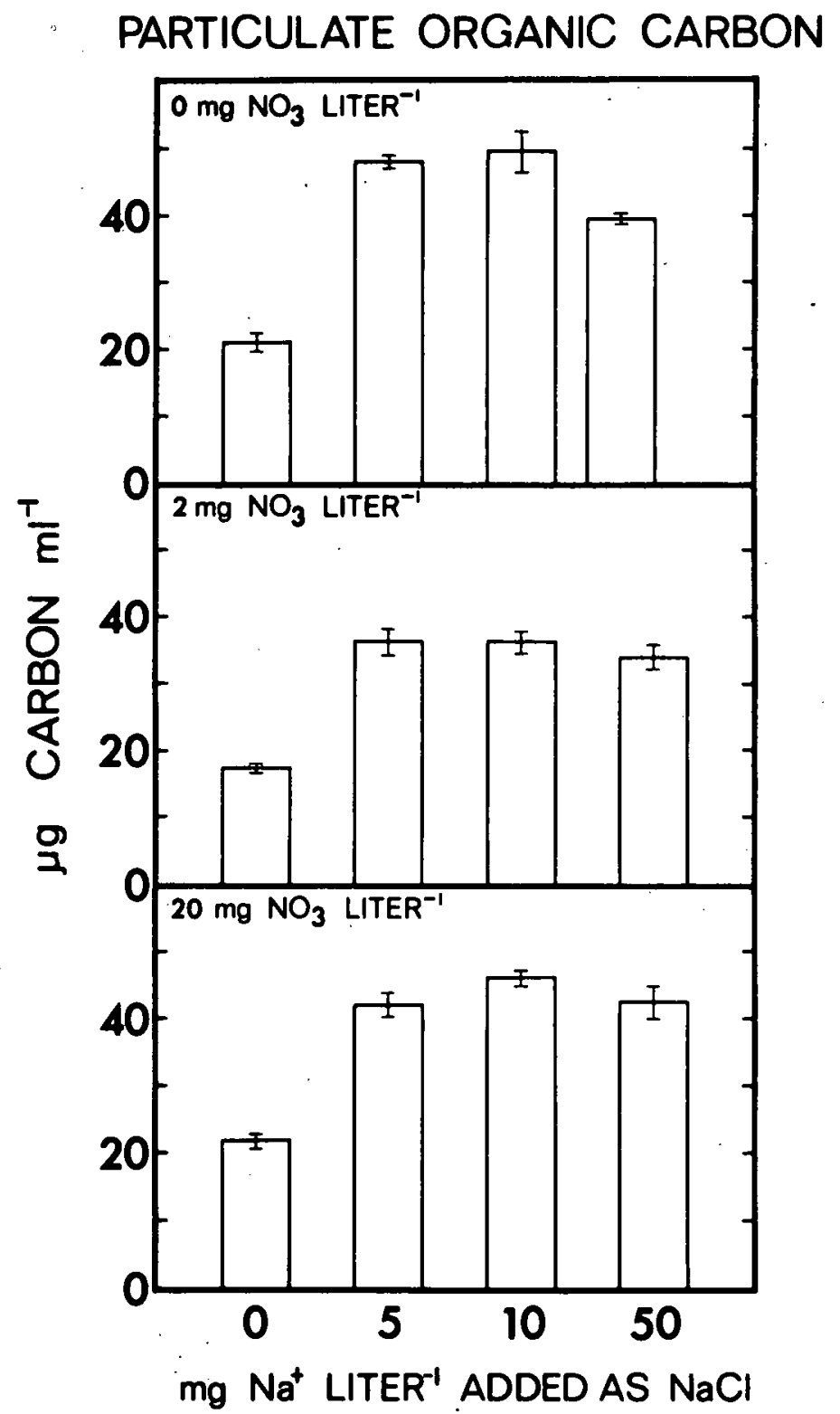

Figure 4. Concentration of particulate organic carbon ( \pm S.D.) of axenic Anabaena cylindrica on day 14 . 
highly significant results $(P \leq 0.01)$ in all areas for which measurements are available (Table 1). Differing concentrations of nitrate produced significant results in four areas: acetylene reduction $(P \leq 0.01)$, heterocyst numbers $(P \leq 0.01)$, particulate organic nitrogen $(P \leq 0.05)$, and excreted organic carbon as percent ${ }^{14} \mathrm{C}$ assimilated $(P \leq 0.01)$. Three of the four areas are associated closely with facets of nitrogen metabolism. The addition of $2 \mathrm{mg} \mathrm{NO}_{3}$ liter $^{-1}$ appeared to make little difference in rates of acetylene reduction at either concentration of sodium compared to rates at $0 . \mathrm{mg} \mathrm{NO}_{3}$ liter ${ }^{-1}$ (Figure 5). However, the addition of $20 \mathrm{mg} \mathrm{NO}_{3}$ liter $^{-1}$ decreased the rates of acetylene reduction compared to 0 and $2 \mathrm{mg} \mathrm{NO}_{3} \mathrm{liter}^{-1}$ at both levels of sodium. Cultures grown at $5 \mathrm{mg} \mathrm{Na}^{+}$liter $^{-1}$ continued to increase in rates of acetylene reduction through day 14 , whereas cultures grown at $0 \mathrm{mg} \mathrm{Na}^{+} 1$ iter $^{-1}$ and $20 \mathrm{mg} \mathrm{NO}_{3}$ liter ${ }^{-1}$ reached a maximum on day 11 and decreased to a. negligible rate by day 14 .

Heterocysts, generally accepted as the sites of nitrogen fixation under externally aerobic conditions (Wolk, 1973), decreased in numbers at higher concentrations of nitrate in both sodium sufficient and sodium deficient cultures. Cultures treated with the lowest sodium concentration ( $0 \mathrm{mg} \mathrm{Na}^{+} 1$ liter $\left.^{-1}\right)$ and highest nitrate concentration (20 mg nitrate liter ${ }^{-1}$ ) were the only ones having fewer heterocysts $\mathrm{ml}^{-1}$ than filaments $\mathrm{ml}^{-1}$ (Figure 6). 
Table 1.--Results of two-way analysis of variance on data from axenic cultures of Anabaena cylindrica in response to sodium and nitrate, including levels of significance: **, $\mathrm{P} \leq 0.01 ; *, \mathrm{P} \leq 0.05 ; \mathrm{n} . \mathrm{s}$. , not significant.

\begin{tabular}{|c|c|c|c|}
\hline & Sodium & Nitrate & $\mathrm{S} \times \mathrm{N}$ \\
\hline Acetylene reduction & ** & ** & n.s. \\
\hline Heterocyst numbers & $\star \star$ & ** & * \\
\hline Particulate organic nitrogen & $\star \star$ & * & n.s. \\
\hline${ }^{14} \mathrm{C}$ assimilation & * $\star$ & n.s. & n.s. \\
\hline Excreted organic carbon & $\star \star$ & n.s. & n.s. \\
\hline Particulate organic carbon & $\star \star *$ & n.s. & n.s. \\
\hline \& Excreted organic carbon & ** & ** & * \\
\hline Chlorophyll a & $\star \star$ & n.s. & n.s. \\
\hline Filament numbers & $\star \star$ & n.s. & n.s. \\
\hline
\end{tabular}




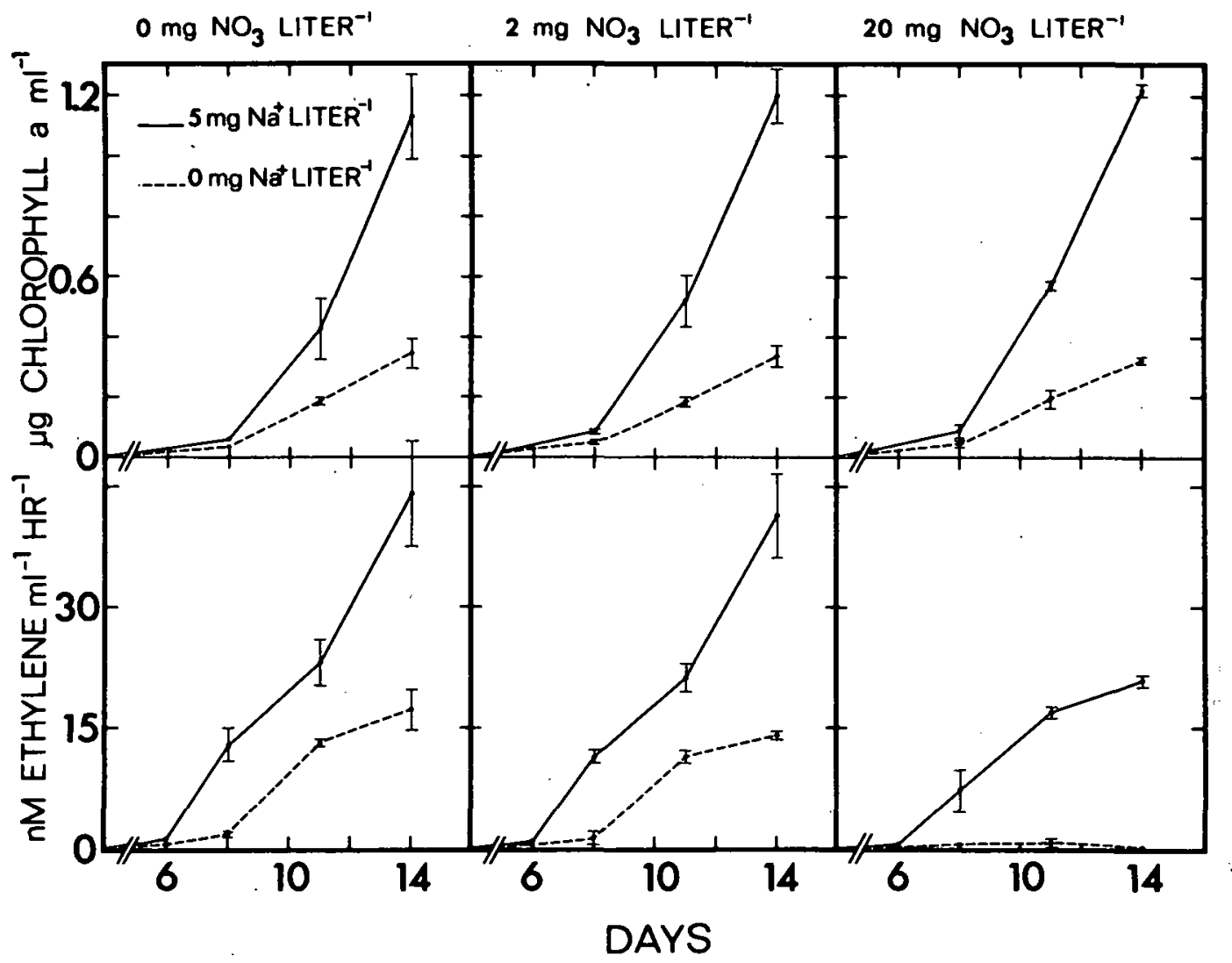

Figure 5. Concentration of chlorophyll a and rates of acetylene reduction of Anabaena cylindrica over time at two concentrations of sodium and three concentrations of nitrate. Standard deviations are included unless one standard deviation was less than the diameter of the point. 


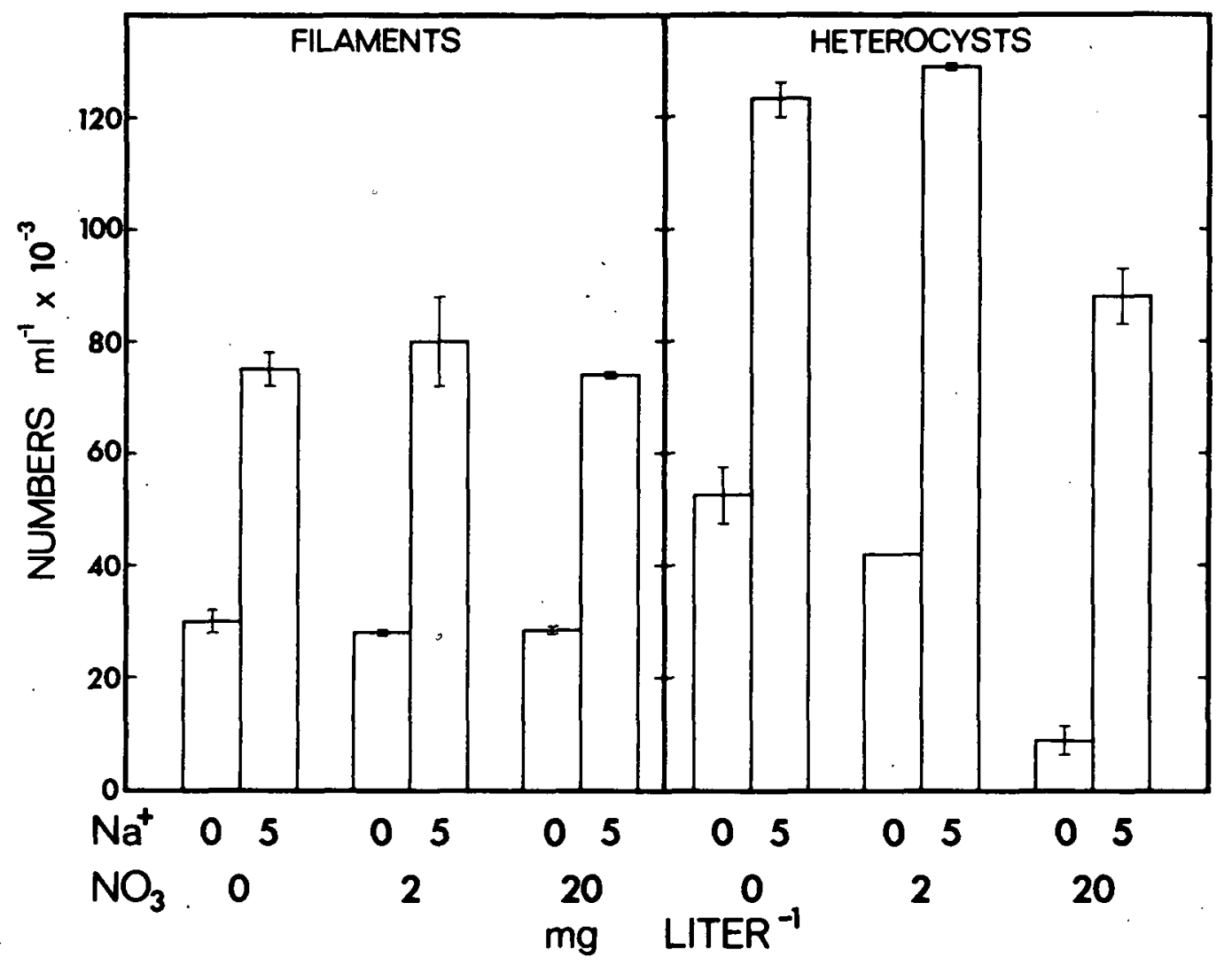

w

Figure 6. Density of filaments and heterocysts $\left(\mathrm{ml}^{-1}\right)$ on day 14 of axenic Anabaena cylindrica in response to variations in sodium and nitrate: . Standard deviations are included unless one standard deviation was less than the width of the line. 
Particulate organic nitrogen content of cultures grown with $5 \mathrm{mg} \mathrm{Na}^{+}$liter ${ }^{-1}$ did not vary with increasing nitrate concentration (Figure 7), indicating that cultures grown at the higher nitrate concentrations, where acetylene reduction decreased, were efficiently supplementing elemental nitrogen fixation with reduction of nitrate. However, sodium deficient cultures decreased in particulate organic nitrogen with increasing nitrate concentration, indicating a lag in nitrogen assimilation at higher concentrations of nitrate.

Particulate organic carbon, rates of ${ }^{14} \mathrm{C}$ assimilation, and rates of excretion of organic carbon (Figures 7 and 8 ) did not vary with increases in nitrate concentration. As in the other experiments, particulate organic carbon in sodium sufficient cultures (5 mg $\mathrm{Na}^{+}$ liter ${ }^{-1}$, was approximately twice that in sodium deficient cultures, whereas rates of ${ }^{14} \mathrm{C}$ assimilation were approximately three times greater. The percentage of ${ }^{14} \mathrm{C}$ assimilated and then excreted as organic carbon increased with increasing nitrate concentration in sodium deficient cultures (Figure 9).

In summary, when no sodium was added to cultures of Anabaena cylindrica, rates of acetylene reduction, ${ }^{14} \mathrm{C}$ assimilation, and excretion of organic carbon were significantly reduced as well as concentrations of chlorophyll a and particulate organic carbon compared with cultures grown with 5, 10, and $50 \mathrm{mg} \mathrm{Na}{ }^{+}$liter $^{-1}$. No marked differences 


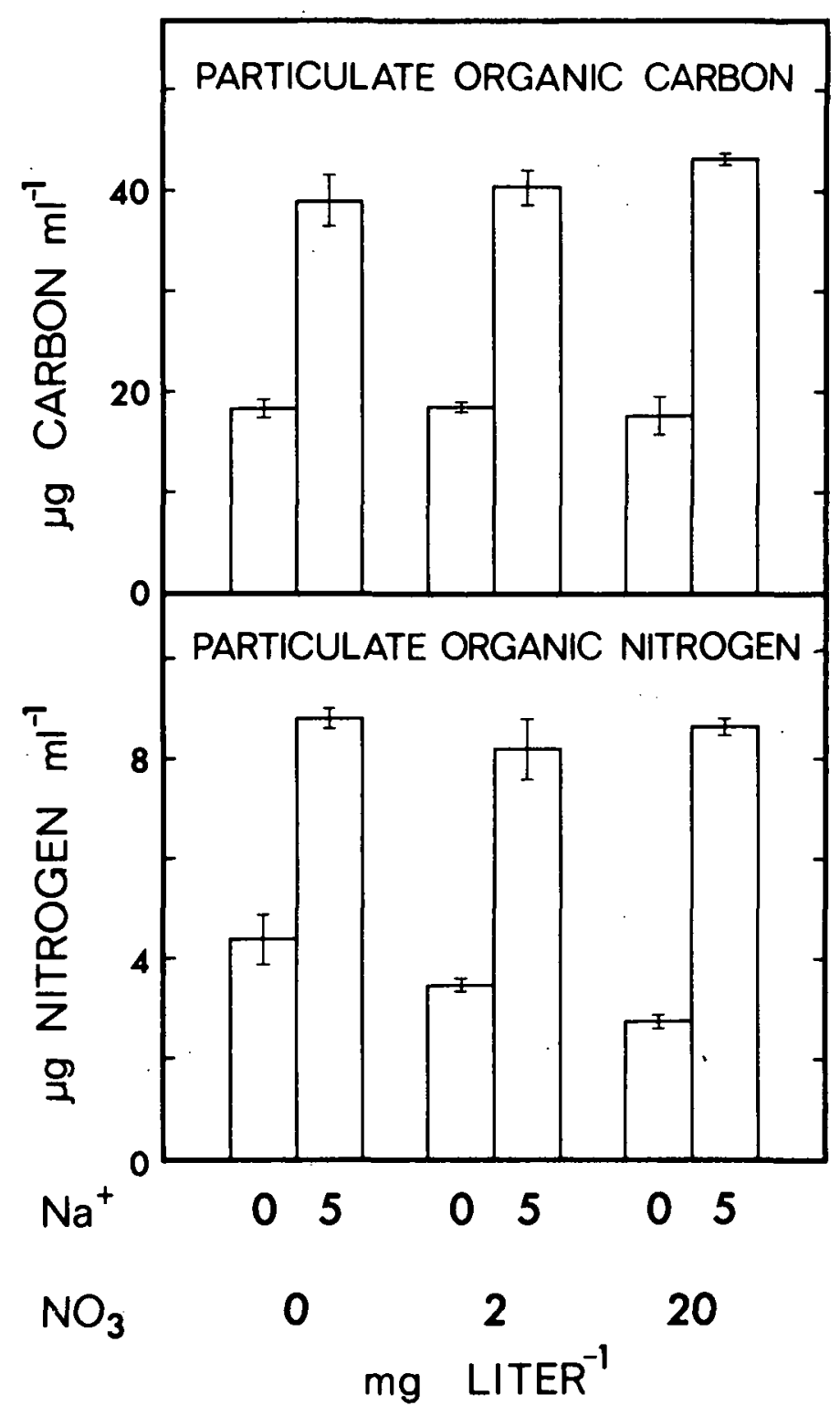

Figure 7. Concentrations (+ S.D.) of particulate organic carbon and particulate organic nitrogen on day 14 of Anabaena cylindrica in response to variations in sodium and nitrate. 


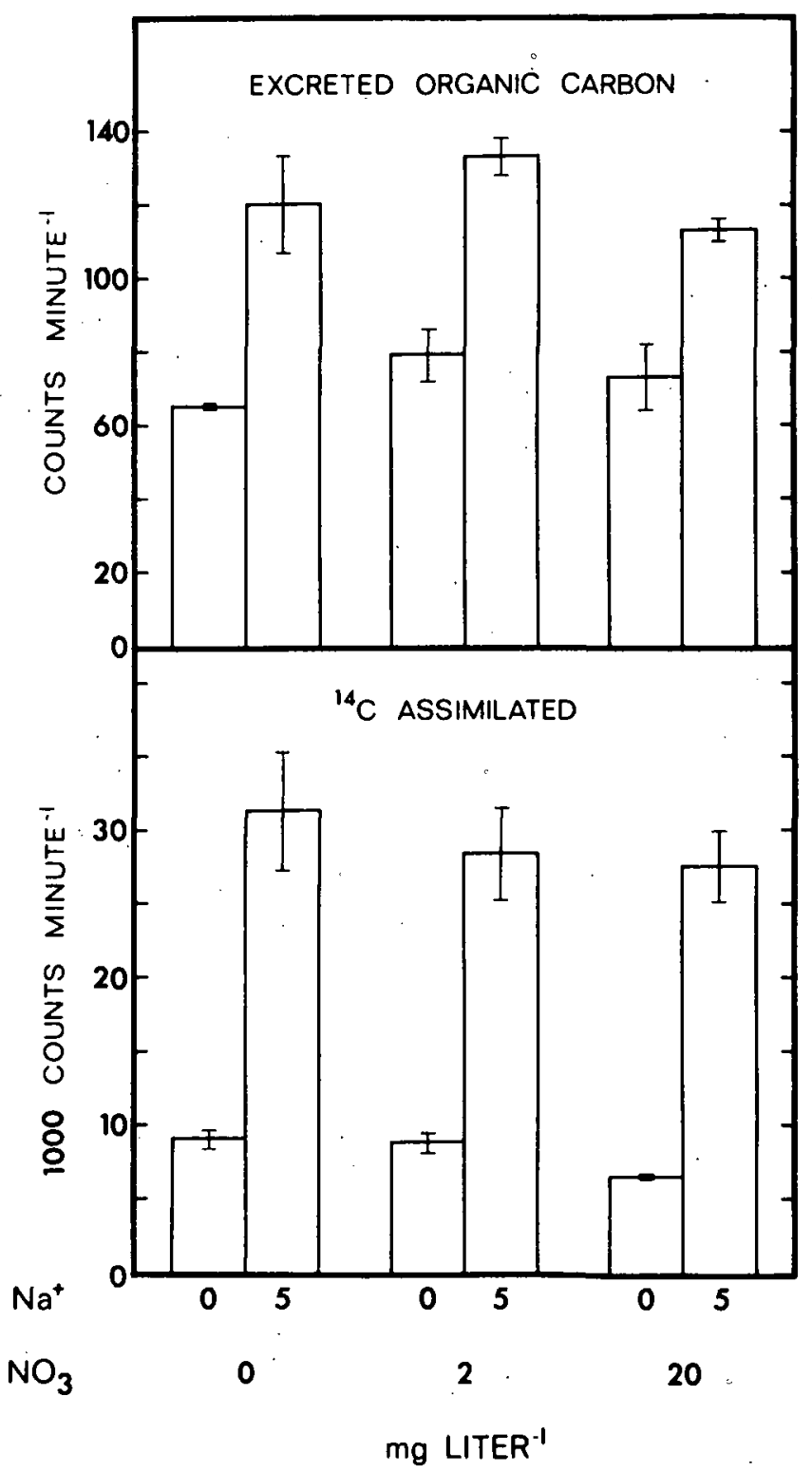

Figure 8. Rates of ${ }^{14} \mathrm{C}$ assimilation and excretion of organic carbon $(+$ S.D.) on day 14 of Anabaena cylindrica in response to varying sodium and nitrate. 
EOC AS \%

CARBON ASSIMILATED

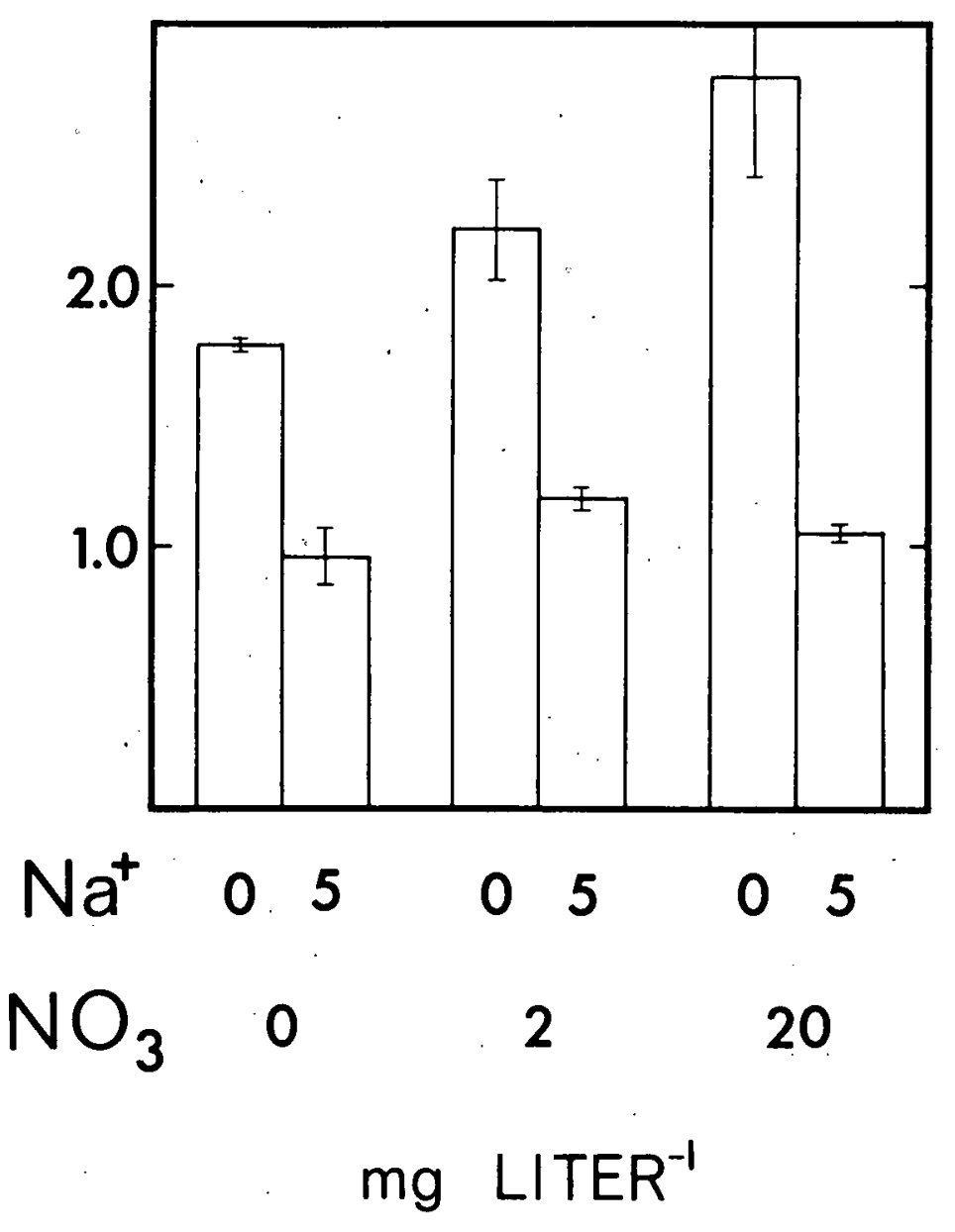

Figure 9. Excreted organic carbon as percentage carbon assimilated ( \pm S.D.) on day 14 of Anabaena cylindrica in response to varying sodium and nitrate. 
were found in cultures supplied with 5,10 , and $50 \mathrm{mg} \mathrm{Na}{ }^{+}$ liter ${ }^{-1}$. Increases in nitrate concentrations resulted in a decrease in acetylene reduction and heterocyst number in both sodium deficient and sodium sufficient cultures; however, a decrease in particulate organic nitrogen was observed only in sodium deficient cultures as nitrate concentrations were increased. An increase in the percentage organic carbon excreted was also apparent in sodium deficient cultures with increasing nitrate concentrations. The effects of high nitrate concentrations on sodium deficient cultures observed in this study are congruous with the results reported by Brownell and Nicholas (1967) in which toxic levels of nitrite accumulated when nitrate was present in sodium deficient cultures. That nitrite was accumulating in sodium deficient cultures in this study is a possibility; however, if so, it did not affect significantly aspects of carbon metabolism (rates of ${ }^{14} \mathrm{C}$ assimilation, excretion of organic carbon and particulate organic carbon) by day 14 of the incubation period. Highest nitrate concentrations used in this study $120 \mathrm{mg}$ $\mathrm{NO}_{3}$ liter $^{-1}$ ) were much lower than those used in the Brownell and Nicholas (1967) study (10 $\mathrm{mM} \mathrm{KNO}_{3}$ ) and are closer to those found in natural aquatic systems.

Response of Natural Populations of Blue-green Algae to Sodium Enrichment

In situ investigations were initiated in order to describe the response of natural populations of 
heterocytous blue-green algae to additions of sodium. Typically, the cation composition of hard-water, marl lakes of southwestern Michigan is completely dominated by calcium and magnesium. The preponderance of divalent cations and the consequent low monovalent:divalent cation ratio has been proposed as one factor, among several, which functions in a cyclical manner to suppress productivity in marl lakes (Wetzel, 1969).

Enrichment studies were conducted in the summers of 1973 and 1974 in Wintergreen Lake, a eutrophic hardwater system which receives significant amounts of allochthonous and autochthonous organic input. The sodium concentrations rarely deviate from approximately $5 \mathrm{mg} \mathrm{Na}^{+}$ liter ${ }^{-1}$, a concentration differing little from that of other more oligotrophic hard-water lake systems in the area. Extensive work has been done on the lake describing basic limnological parameters as well as studies with particular emphasis on carbon and nitrogen metabolism (Duong, 1972; Manny, 1972; and Wetzel, et al., 1974). Characteristically, a dense heterocystous blue-green population develops in the summer; it was during a period of such development that the enrichment experiments were conducted.

Figure 10 illustrates the effects of sodium added in concentrations of 50,100 , and $200 \mathrm{mg} \mathrm{Na}^{+} 1 \mathrm{iter}^{-1}$ above background lake water $\left(4.98 \mathrm{mg} \mathrm{Na}^{+}\right.$liter $\left.{ }^{-1}\right)$ at a depth of one meter. The predominant alga in the phytoplankton was 


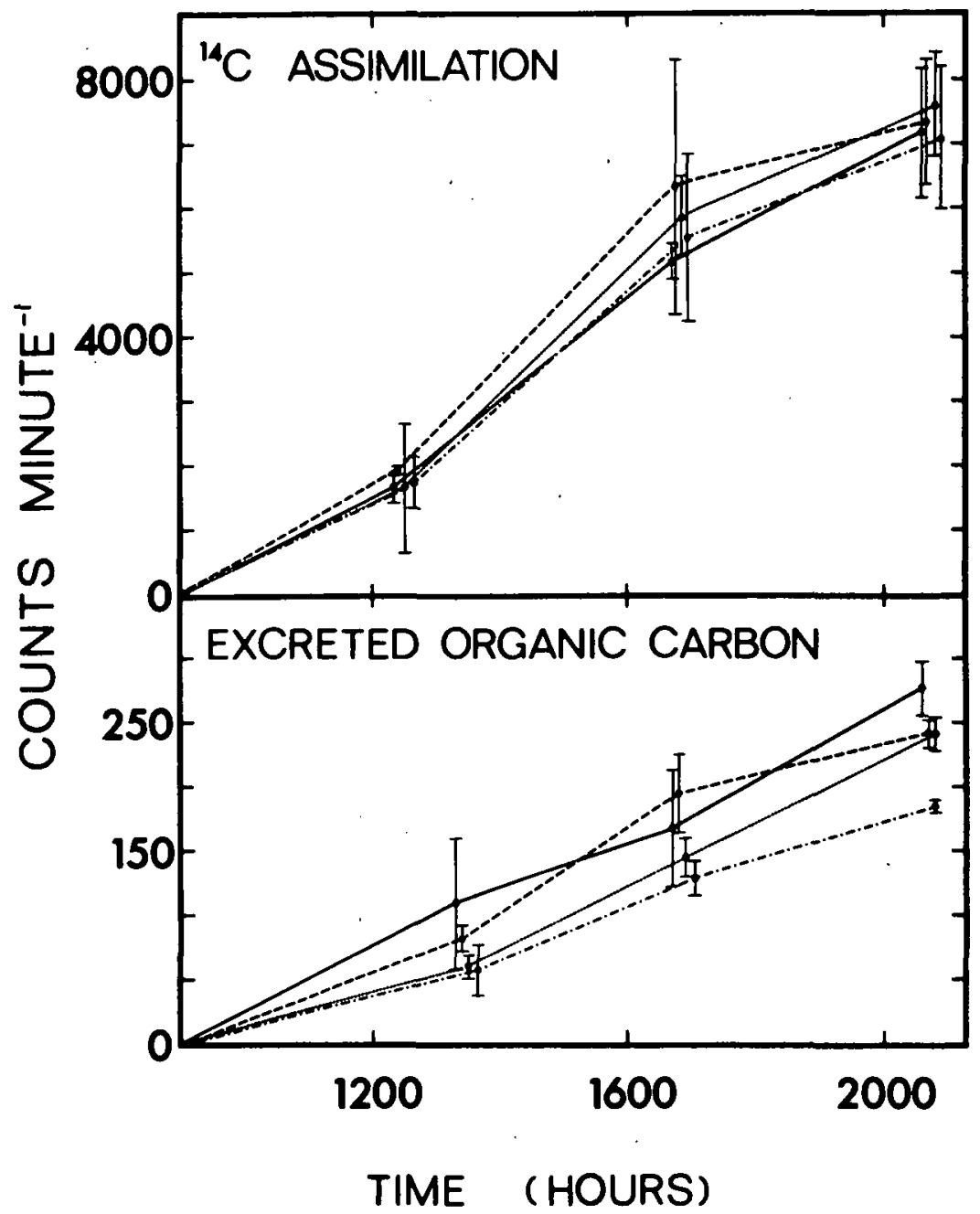

Figure 10. Photosynthetic carbon fixation and excreted organic carbon of phytoplankton populations in response to sodium enrichment, $16 \mathrm{July} 73$, in Wintergreen Lake over a 12-hour incubation period. Llakewater control. ; $50 \mathrm{mg}_{1} \mathrm{Na}$ liter $^{-1} \cdot \mathrm{mg} \mathrm{Na}^{+}$ $100 \mathrm{mg} \overline{\mathrm{Na}}+{ }^{+} l i t$
liter 
Aphanizomenon sp. Although no marked enhancement of photosynthetic carbon fixation was observed over untreated lakewater controls, neither was there a marked suppression over a 12-hour incubation period, which supplies further evidence for the halotolerant nature of blue-green algae (Pillai, 1954, 1955; Bàtterton \& Van Baalan, 1971). In contrast to these results were those illustrated in Figure 11 in which a two- to three-fold stimulation in photosynthetic carbon fixation was caused by the addition of $5 \mathrm{mg} \mathrm{Na}^{+}$liter ${ }^{-1}$ over background lakewater $\left(4.99 \mathrm{mg} \mathrm{Na}^{+}\right.$ liter ${ }^{-1}$ ) over a four hour incubation period. The addition of $50 \mathrm{mg} \mathrm{Na}^{+}$liter ${ }^{-1}$ caused highly erratic results. The same concentrations of sodium did not increase the rates of acetylene reduction (Figure 11). Again, the dominant phytoplankter was Aphanizomenon (Table 2). These preliminary bioassays suggest that, whereas the addition of large quantities of sodium have no effect on photosynthetic carbon fixation in this system, the addition of small quantities of sodium does enhance carbon fixation. The development and associated literature of bioassay studies as a tool in understanding nutrient relationships in laboratory cultures and in natural populations as well as the advantages and disadvantages of such a technique have been discussed by Wetzel (1965b). Ideally, enrichment bioassays provide a rapid determination of nutrients which may be in short supply and, hence, limiting productivity among natural phytoplankton populations. Problems exist 


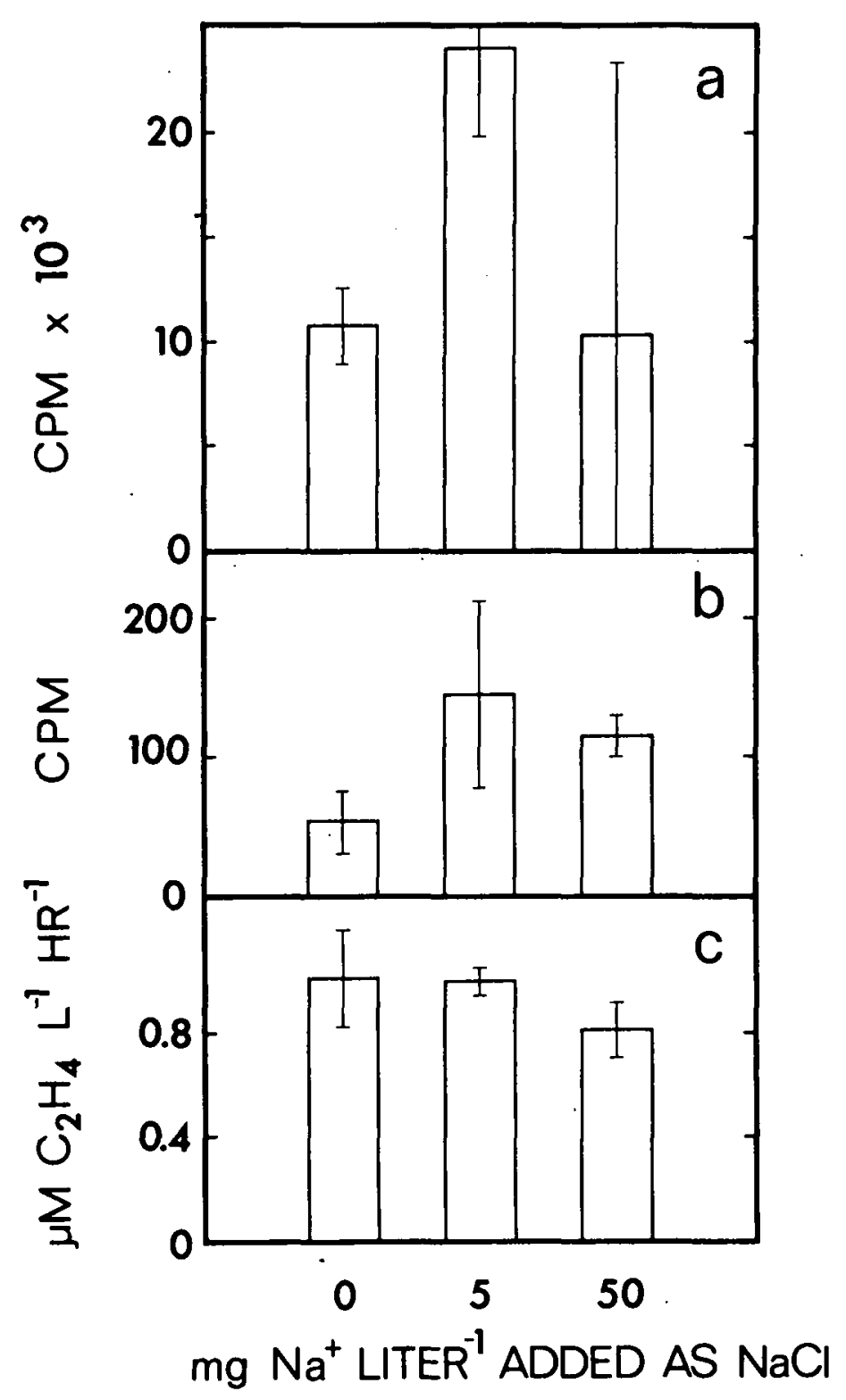

Figure 1l. (a) Photosynthetic carbon fixation, (b) rates of excretion of organic carbon, and

(c) acetylene reduction of phytoplankton populations in response to sodium enrichment, 11 July 74, in Wintergreen Lake at 0.5 meters. $0=$ lakewater control ( \pm S.D.). 
Table 2.--Major groups of algae present on $11 \mathrm{July} 74$ at $0.5 \mathrm{M}$ in wintergreen Lake.

Genus

Aphanizomenon sp.

filaments

heterocysts

Anabaena sp.

filaments

heterocysts

Microcystis sp.

Ceratium sp.

Cryptomonas sp.

Trachelomonas sp.
Number liter ${ }^{-1}$

$16,524,300$

$2,988,200$

89,200

22,300

22,300

423,700

178,400

66,900

in interpretation in that the response of a population may vary not only among aquatic systems, but with time and at differing concentrations of the added nutrient due to changes in interacting factors within the system as well as the interaction of such factors with the added nutrient. The interpretation is compounded further when the physiological function of the compound in unknown. The initial bioassays performed in this study are certainly subject to all of the above problems of interpretation. Although sodium concentrations vary little within wintergreen Lake throughout the year, components which may alter the response to sodium may vary. More specifically, the response of the Aphanizomenon population may vary within the period of the bloom. The population used in the 
enrichments of 1974 was extraordinarily dense (16 million filaments liter ${ }^{-1}$ ) and crashed dramatically a few days after the bioassays. That the population was stressed during the period of the experiment is probable; that this "stressed" condition is related to the positive response to added sodium is speculative.

Obviously, many questions remain with regard to the role of sodium in aquatic systems, particularly as it affects blue-green algal populations. Although direct extrapolation from axenic laboratory cultures is impossible, laboratory studies, by minimizing lack of control, make it possible, among other functions, to pinpoint areas of potential importance to natural populations. The response of sodium deficient cultures to nitrate in this study as well as the results reported by Brownell and Nicholas (1967) that sodium inhibits nitrate reductase suggest intriguing possibilities for the role of sodium in aquatic systems in terms of interactions between inorganic and elemental nitrogen assimilation. 
SUMMARY AND CONCLUSIONS

The response of axenic cultures of Anabaena cylindrica to four concentrations of sodium and three concentrations of nitrate were examined with special emphasis on aspects of nitrogen and carbon metabolism. In situ sodium enrichment bioassays were employed to ascertain the response of natural populations of heterocystous bluegreen algae to additions of sodium. The acetylene reduction technique was used as a comparative measure of the $\mathrm{N}_{2}$-fixing ability of blue-green algae, and the assimilation of inorganic radioactive carbon provided a means of determining rates of photosynthetic carbon fixation. The following conclusions can be drawn from this study:

1. Cultures with no $\mathrm{NaCl}$ added suffered from decreased rates of acetylene reduction, ${ }^{14} \mathrm{C}$ assimilation, excretion of organic carbon as well as lower concentrations of chlorophyll a and particulate organic carbon as compared to cultures supplied with 5,10 , and $50 \mathrm{mg} \mathrm{Na}^{+}$liter ${ }^{-1}$.

2. Sodium deficient cultures released a higher percentage of previously fixed carbon as organic 
carbon, possibly indicating a less efficient system in terms of carbon utilization.

3. No differences in any area measured were demonstrable among cultures grown with 5,10 , and $50 \mathrm{mg}$ $\mathrm{Na}^{+}$liter ${ }^{-1}$.

4. High nitrate concentrations (20 $\mathrm{mg} \mathrm{NO} \mathrm{N}_{3}$ liter $^{-1}$ ) resulted in decreased rates of acetylene reduction and heterocyst numbers in sodium sufficient and sodium deficient cultures; however, decreased particulate organic nitrogen content at high levels occurred only in sodium deficient cultures.

5. Higher percentages of excreted organic carbon occurred with increasing nitrate concentrations in sodium deficient cultures.

6. Preliminary sodium enrichment bioassays performed in Wintergreen Lake indicated increased photosynthetic carbon fixation with small additions of sodium ( $5 \mathrm{mg} \mathrm{Na}^{+}$liter ${ }^{-1}$ ). Higher concentrations (50, 100, and $200 \mathrm{mg} \mathrm{\textrm {Na } ^ { + }}$ liter ${ }^{-1}$ ) elicited neither a stimulatory nor an inhibitory response in carbon fixation over untreated lakewater controls.

7. No increase in in situ acetylene reduction rates occurred among natural populations with additions of sodium over the short incubation period utilized. 


\section{BIBLIOGRAPHY}




\section{BIBLIOGRAPHY}

Allen, M. B. 1952. The cultivation of Myxophyceae. Arch. Mikrobiol. 17:34-53.

Allen, M. B., and D. I. Arnon. 1955. Studies on nitrogenfixing blue-green algae. II. The sodium requirement of Anabaena cylindrica. Physiologia Plantarum. $\underline{8}: 653-66 \overline{0}$.

Batterton, J. C., and C. Van Baalan. 1971. Growth responses of blue-green algae to sodium chloride concentration. Arch. Mikrobiol. 76:151-165.

Benecke, W. 1898. Uber Culturbedingungen einiger Algen. Bot. Zeit. 56:83.

Brownell, P. F., and D. J. D. Nicholas. 1967. Some effects of sodium on nitrate assimilation and $\mathrm{N}_{2}$ fixation in Anabaena cylindrica. Plant Physiol. 242:915-921.

Dilworth, M. 1966. Acetylene reduction by nitrogen-fixing preparation from Clostridium pasteurianum.

Biochem. Biophys. Acta. 127:285-291.

Dugdale, V. A., and R. C. Dugdale. 1965. Nitrogen metabolism in lakes. III. Tracer studies of the assimilation of inorganic nitrogen sources. Limnol. Oceanogr. 10:53-57.

Duong, T. P. 1972. Nitrogen fixation and productivity in a eutrophic hard-water lake: In situ and laboratory studies. Ph.D. dissertation, Michigan state University. $241 \mathrm{pp}$.

Edmondson, W. T., G. C. Anderson, and D. R. Peterson. 1956. Artificial eutrophication of Lake Washington. Limnol. Oceanogr. 1:47-53.

Emerson, R., and C. M. Lewis. 1942. The photosynthetic efficiency of phycocyanin in Chroococcus and the problem of carotenoid participation in photosynthesis. J. Gen. Physio. 25:579. 
Fogg, G. E., W. D. P. Stewart, P. Fay, and A. E. Walsby. 1973. The Blue-green Algae. Academic Press, New York. 459 pp.

Gerloff, G. C., G. P. Fitzgerald, and F. Skoog. 1952. The mineral nutrition of Microcystis aeruginosa.

Amer. J. Bot. 39:26-32.

Goering, J. J., and R. C. Dugdale. 1966. Estimates of in situ rates of nitrogen uptake by Trichodesmium sp. in the tropical Atlantic Ocean. Limnol. Oceanogr. 11 : $614-620$.

Goering, J. J., and J. C. Neess. 1964. Nitrogen fixation in two Wisconsin lakes. Limnol. Oceanogr. $\underline{9}: 535-539$.

Horne, A. J., and G. E. Fogg. 1970. Nitrogen fixation in some English lakes. Proc. Roy. Soc. Lond. B. $175: 351-366$.

Horne, A. J., and C. R. Goldman. 1972. Nitrogen fixation in Clear Lake, Calif. I. Seasonal variation and the role of heterocysts. Limnol. Oceanogr. $17: 678-692$.

Horne, A. J., J. E. Dillard, D. K. Fujita, and C. R. Goldman. 1972. Nitrogen fixation in Clear Lake, Calif. II. Synoptic studies on the autumn Anabaena bloom. Limnol. Oceanogr. 17:693-703.

Kratz, W. A., and J. Myers. 1955. Nutrition and growth of several blue-green algae. Amer. J. Bot. $\underline{42}: 282-287$.

Manny, B. A. 1972. Seasonal changes in organic nitrogen content of net- and nannophytoplankton in two hard-water lakes. Arch. Hydrobiol. 71:103-123.

McKenzie, H. A., and H. S. Wallace. 1954. The Kjeldahl determination of nitrogen: A critical study of digestion conditions--temperature, catalyst, and oxidizing agent. Aust. J. Chem. $7: 55-70$.

Parsons, T. R., and J. D. H. Strickland. 1963. Discussion of spectrophotometric determination of marine plant pigments, with revised equations for ascertaining chlorophylls and carotenoids. J. Mar. Res. $21: 155-163$. 
Pillai; V. K. 1954. Growth requirements of a halophilic blue-green alga, Phormidium tenue (Menegh). Indian J. Fish. 1 :130-144.

Pillai, V. K. 1955. Observations on the ionic composition of blue-green algae growing in saline lagoons. Proc. Nat. Inst. Sci. India, Part B. Biol. Sci. 21: 90-102.

Provasoli, L. 1969. Algal nutrition and eutrophication. In Eutrophication: Causes, Consequences, Correctives. National Academy of Sciences, Washington, D.C. pp. 574-593.

Schöllhorn, R., and R. H. Burris. 1966. Study of intermediates in nitrogen fixation. Fed. Proc. 24:710.

Stewart, W. D. P. 1973. Nitrogen Fixation. pp. 260-278. In: N. G. Carr and B. A. Whitton, eds. The Biology of Blue-green Algae. University of California Press, Berkeley.

Stewart, W. D. P., G. P. Fitzgerald, and R. H. Burris. 1967. In situ studies on $\mathrm{N}_{2}$ fixation using the acetylene reduction technique. Proc. Nat. Acad. Sci. U.S.A. 58:2071-2078.

Stewart, W. D. P., G. P. Fitzgerald, and R. H. Burris. 1968. Acetylene reduction by nitrogen-fixing bluegreen algae. Arch. Mikrobiol. 62:336-348.

Stewart, W. D. P., T. Mague, G. P. Fitzgerald, and R. H. Burris. 1971. Nitrogenase activity in Wisconsin lakes of differing degrees of eutrophication. New Phytol. 70:497-509.

Strickland, J. D. H., and T. R. Parsons. 1968. A Practical Handbook of Seawater Analysis. 2nd edition. Bull. Fish. Res. Bd. Canada, 167. 309 pp.

Westlake, D. F. 1969. Estimating quantity and quality of biomass--Macrophytes. pp. 25-32. In: R. A.

Vollenweider, ed. A manual on methods for measuring primary production in aquatic environments. Blackwell Scientific Publication, Oxford.

Wetzel, R. G. 1965a, Necessity for decontamination of filters in $\mathrm{C}^{14}$ measured rates of photosynthesis in fresh waters. Ecology. 46:540-542. 
Wetzel, R. G. 1965b. Nutritional aspects of algal productivity in marl lakes with particular reference to enrichment bioassays and their interpretation. Mem. Ist. Ital. Idrobiol., 18 Suppl.:137-157.

Wetzel, R. G. 1966. Variations in productivity of Goose and hypereutrophic Sylvan lakes, Indiana. Invest. Indiana Lakes and Streams. $7(5): 147-184$.

Wetzel, R. G. 1969. Factors influencing photosynthesis and excretion of dissolved organic matter by aquatic macrophytes in hard-water lakes. Verh. int. Ver. Limnol. 17:72-85.

Wetzel, R. G., and D. F. Westlake. 1969. Estimating quantity and quality of biomass--Periphyton. pp. 33-40. In: R. A. Vollenweider, ed. A manual on methods for measuring primary production in aquatic environments. Blackwell Scientific Publication, Oxford.

Wetzel, R. G., B. A. Manny, W. S. White, R. A. Hough, and K. R. McKinley. 1974. Wintergreen Lake: A study in hypereutrophication. (In prep.).

Wolk, C. P. 1973. Physiology and cytological chemistry of blue-green algae. Bacteriol. Rev. 37:32-101. 